\title{
Coal Mining and Human Rights: Initiating The Right To a Good and Healthy Environment as Non-Derogable Right
}

\author{
Jalaluddin \\ Antasari State Islamic University, Banjarmasin. \\ Jalaluddin@uin-antasari.ac.id
}

\begin{abstract}
The impact of the larger amount of exploited coal causes enormous environmental damage. This sociological legal research finds that coal mining activities have caused human rights abuses because of the loss of a good and healthy environment for society. Whereas according to Article $28 H$ of the 1945 Constitution of the State of the Republic of Indonesia that every person has the right to live in a good and healthy environment. Also in Article 9 paragraph (3) of Act No. 39 of 1999 on Human Rights states that everyone has the right to live in a good and healthy environment. Furthermore, this study found human rights violations that occurred because the act relating to the management of this mining environment is not enforced. Both acts relate to environmental management in its mining process as well as laws relating to environmental management after coal mining activities by mining companies. This happens because the law enforcement apparatus does not take appropriate action as set forth in the related law. Interviews and observation data shows that law enforcement officers are a part related to coal mining activities in South Kalimantan. The law enforcement authorities take advantage of non-compliant companies to the law relating to the management of the mining environment resulting in environmental degradation and human rights violations. It seems that cases like this do not only happen in Indonesia, they also happen in other countries. Therefore, the right to a good and healthy environment should be promoted as a nonderogable right.
\end{abstract}

Keywords- State; Good and Healthy Environment; NonDerogable Right; Coal Mining; Human Right;

\section{INTRODUCTION}

The right to the environment is a fundamental right for human beings. The right is inherent to strengthen the constructs of human life. The right to a clean environment is included in the category of third generation human rights, namely the right to development, the right to peace, and the right to a clean environment (Tomuchat, 2003). Unfortunately, this particular right receives little attention, especially from the government and companies. As a result, environmental pollution is always found in mining activities, such as coal mining.

The above description shows that although the right to the environment is a fundamental human right, its conception and implementation has not been conducted properly. Is it possible, therefore, that the right to a good and healthy environment is made as a non-derogable right?

\section{GoOd AND HeAlthy ENVIRONMENT AS THE Human RIGHTS}

The environment as human right finds its momentum in the Stockholm Declaration. The first article of the declaration states that man has the fundamental rights to freedom, equality and adequate conditions of life, in an environment of a quality that permits a life of dignity and well-being, and the bears a solemn responsibility to protect and improve the environment for present and future generations... (Sand, 2004).

Dinah Shelton once states the importance of the momentum that several dozen international treaties adopted science Stockholm Conference call upon states to take specific measures to ensure that the public is adequately informed about environmental risks, including health risks, posed by specific activities. In addition to the right to information, the public is also given broad rights of participation in decisionmaking and access to remedies for environmental harm (Shelton, 2002).

Klaus Toefler, Executive Director of the United Nations Environment Program said that the Stockholm Declaration is an appropriate approach to understand environmental protection that has implications on the fulfillment of human rights. Toefler says human rights cannot be secured in a degraded or polluted environment. The fundamental right to life is threatened by soil degradation and deforestation and by exposures to toxic chemicals, hazardous wastes and contaminated drinking water. Environmental conditions clearly help to determine the extent to which people enjoy their basic rights to life, health, adequate food and housing, and traditional livelihood and culture. It is time to recognize that those who pollute or destroy the natural environment are not just committing a crime against nature, but are violating human rights as well. (Shelton, 2002).

The Stockholm Declaration was followed by a Montevideo meeting. This meeting was an ad hoc meeting of senior expert officials in environmental law on 28 October to 6 November 1981. This meeting established frameworks, methods and programs, including international, national and local level efforts for the development and environmental law in Systemwide, Medium Term Environment Program, United Nations Environment Program (Machmud, 2007).

Following up on the results that were decided at the Stockholm 1972 convention, in 1983 the United Nations 
established the World Commission on Environment and Development (WCED). This is to comply with the decision of the UN General Assembly in December 1983 Number 38/161. As an independent institution, WCED conducts inventory and provides advice and feedback on global issues (Machmud, 2007).

WCED has submitted a report entitled 'Our Common Future' containing results of investigations into integrated environmental activities and programs regarding issues of economic development at international, national and local levels (Machmud, 2007 and J. Bhagwati, 1995).

In addition to submitting the report, WCED also proposed that an international meeting be held to discuss global environmental issues in relation to sustainable development. The proposal was accepted by the UN General Assembly session resolution 44/228. As the implementation of the resolution, the United Nations Conference on Environment and Development (UNCED) was held in Rio de Janeiro, Brazil.

The Rio de Janeiro Declaration was a declaration made at the United Nations conference on environment and development in Rio de Janeiro, Brazil from June 3 to 14, 1992. It was the greatest and largest conference in the history of international meetings. The meeting was attended by 17 countries and governments, 15,000 people including government representatives led by heads of state or government, attended by no fewer than 9,500 journalists and followed by 1,200 NGOs.

The crucial consent of the Rio de Janeiro conference was the widespread plurality of people of the world to be able to inherit the planet with a sustainable environment to the future generations. It means that the states and governments around the world have an obligation to commit ensuring the fulfillment of a good and healthy environment as the right to good and healthy environment. This commitment can be read in Article 4 of the Rio Declaration which affirms in order to achieve sustainable development, environmental protection shall constitute on integral part of the development process and cannot be considered in isolation from it (Salleh, 2002).

Along with that, the international community has also made important ideas of environmental awareness. In September of 2000, 147 countries from 190 UN participating countries have set one of the most important agendas in the Millennium Development Goals (MDGs) to secure environmental sustainability (El Muhtaj, 2008). Thus, it can be understood that public awareness of the importance of the environment is no longer local normativity, but a common life construct.

The 1945 Constitution of the Republic of Indonesia as the constitution of the state has recognized the right to the environment as human rights. It is affirmed in Article $28 \mathrm{H}$ Paragraph (1) which reads "Every person has the right to live a prosperous and spiritual life, to live, and to get a good and healthy environment and have the right to get health service. The Constitution is the main norm (grand norm) in the regulation of the life of the nation and the state.
In Act No. 39 of 1999 on Human Rights stated in Article 9 paragraph (3) which states "everyone has the right to a good and healthy environment". Act No. 23/1997 on Environmental Management in Article 1 asserts that, "the environment is the unity of space with all things, circumstances and living things, including human beings and their behavior that influence the viability of human life and welfare and other living things". Through this concept, then emerging environmentally sustainable development term. The Act No. 23 referred to in Article 1 paragraph (3) states that sustainable and environmentally sound development is "a conscious and planned effort that integrates the environment, including resources into the development process to ensure the ability, well-being, and quality of life the present generation and the future generation ". This concept then raises the term sustainable development that is environmentally sound. The Act No. 23 referred to in Article 1 paragraph (3) states that sustainable and environmentally sound development is "a conscious and planned effort that integrates the environment, including resources into the development process to ensure the ability, well-being, and quality of life the present and the future generation ".

Article 5 of Act No. 7/2004 on Water Resources states that, "the state guarantees the right of everyone to obtain water for the minimum daily needs to fulfill his healthy, clean, and productive life". In Act No. 23 of 1997 on Environmental Management in Article 5 paragraph (1) states that "everyone has equal rights over a healthy and good environment". Such rights as set forth in paragraph (2) shall also relate to the right to environmental information and to the role of environmental management. The elucidation of Article 5 paragraph (2), Act No. 23/1997 states that "the right to environmental information is a logical consequence of the right to achievement in environmental management based on the principle of openness. The right to environmental information will increase the value and implications of participating in environmental management, in addition to open up opportunities for communities to justify their right to a healthy and healthy environment. The environmental information referred to in this paragraph may be in the form of data, information or other information relating to the environmental management which, by its nature and purpose, is open to public knowledge, such as environmental impact assessment documents, environmental monitoring reports and assessments, monitoring of structuring and monitoring changes in environmental quality and spatial planning ".

The act has provided an enormous opportunity for the communities to participate in environmental management. It is intended that the rights of the people to a good and healthy environment can really be fulfilled. Likewise, in Act No. 32 of 2009 on the Management and Protection of the Environment, Article 44, states "any drafting of laws and regulations on national and regional ranks shall observe the protection of environmental functions and the principles of environmental protection and management in accordance with the provisions stipulated in this law ". Article 47 paragraph (1) of the law states that "any business and or activity that has the potential 
to have significant impacts on the environment, threats to ecosystems and livelihoods, and / or human health and safety shall undertake an environmental risk analysis". Furthermore, Article 5 paragraph (2) states "everyone has the right to environmental information relating to a role in environmental management".

The article shows that environmental information is a right of communities to be fulfilled in the field of environmental management. Another Article which also regulates information concerns is Article 10 letter $\mathrm{h}$ which states that, "In the framework of environmental management, the government is obliged to provide environmental information and disseminate it to the public.

\section{RESEARCH METHOD}

This sociological law research uses a qualitative approach. The research location is Kampung Ness 15 Desa Tatakan, Tapin Selatan District, South Kalimantan. Kampung Ness 15 Tatakan Village was used as the setting of this research because the village operates a mining company and there are damages, such as pollution of river water, rice field, fish pond, damaged rubber plantation, rice field, and air pollution. Violations of the right to a good and healthy environment affect the non-fulfillment of the right to economy, work, health and education, even the right to the comfort of worship is also disrupted. The data were obtained by in-depth interview technique and observation. Interviews were conducted with residents and management companies. The observations were made on areas affected by coal poison.

\section{FINDINGS}

One of the major impacts of coal mining is pollution and environmental degradation. Often these mining actors forget the anticipation or mitigation of the damaging effects of the environment, and this is further exacerbated by the weakness of law enforcement. A definite example is there are large holes that create pools of acidic high water. This acid level is caused by coal excavations containing toxic materials such as iron, sulfate, manganese, and others. These substances will adversely affect the surrounding plants.

There are many more impacts caused by coal mining that ignores the environment. It is very important that there is awareness among mining actors and the public about health and environmental sustainability. In addition, the state and government shoul take big and decisive role in warning or taking action against coal miners who are "naughty".

Coal mining is an industry at risk of accelerating social and cultural and the environment fragility because it only take account on economic value and ignore other values. Environmental damages such as river water pollution, wetland water, rubber land and pollution of the village are increasingly widespread and have become a burden for the local citizens. Mining companies will not suffer losses due to environmental damage and social-cultural fragility, but the citizens and the local governments continue to face losses by enduring the ever-increasing costs of value. The remaining coal laundry in the pool is very dangerous because it contains toxic metals more dangerous than the process of purifying gold mining using toxic substances. The washing process is done to make the coal cleaner and purer so it has a high selling value. This process is done because at the time of exploitation done, coal is usually mixed with soil and other rocks that reduce the purity of coal. To make it easier and cheaper, a pond for washing is made. The pool contains mud-water washing water (coal residue). If the residue is mixed with the river water and the river water is used by the community continuously, then the various symptoms of the disease will appear after the poisonous substances accumulate in the human body. The elements contained in it, such as beranu, cause skin diseases, digestive disorders, lungs and brain cancer.

Unlike the tailings, the residue of the gold mining, the heavily weighted element of heavy metals in coal mining remains much more dangerous. Unfortunately, until now there has been no publishing or information from the mining companies to communities around the mine about the danger of sludge.

Other observational data on the negative impacts of coal mining are the drastic decline in the ability of people to shop for their primary needs. Different things happened when people still had the income from the production of rubber plantations and rice crops. Their rubber plantation and paddy farms are no longer making much money so the people's economy is very weak.

As a result of the rubber plantations that do not provide income, the rubber farmers have to sell vehicles to cover the needs of everyday life. There are also those who have to withdraw their savings from the bank for their children educational purposes. They say, what would happen to their life if they have lost their source of income to survive? Perhaps they said, their children had to quit school because they no longer have money.

So, it is ironic if the right to a good and healthy environment is not fulfilled because it will impact the nonfulfillment of human rights in other fields. A good and healthy environment becomes the foundation and construction for the fulfillment of other human rights fields.

\section{DISCUSSION}

During the life of the nation and the state of Indonesia today, the hopes and ideals of social justice are increasingly difficult to achieve. In fact, it can be said that these ideals continue to be forgotten. Many of the phenomena in society show how a nation that explicitly mentions social justice in its Pancasila ideology, seems to ignore the ideals of the common good. One obvious example is the coal mining policy that does not bring prosperity, but it brings misery and misfortune to society. The facts prove that coal mining is threatening the welfare of society and environmental sustainability. The coal mining policy has failed to realize the ideals of social justice as has been the case in many other countries (Rivkin, 2010). Coal mining causes farmers' incomes to decline due to the destruction of their farms and even changes in agricultural 
land into mining areas (Prajna Paramita Mishra and Ayan Kumar Pujari).

Therefore, it can be said that coal mining is an activity that obtain metals and minerals by destroying mountains, forests, rivers, seas, and villagers. Others say that coal mining is one of the most destructive activities of nature and social life, owned by the rich and only benefiting the rich. There is also a saying that coal mining is an industry that spread many myths and lies. Based on these definitions, there are number of elements that are definitely inherented in coal mining, namely the existence of destructive, lies, myths, and gains for a handful of certain people (the rich). The damage caused to both the environment and the social life of the community is considered too risky (Khalid, 2009).

Judge Christoper Weeramantry, former US Supreme Court Justice, once wrote that environmental protection is an important part of contemporary human rights doctrine, because it is a sine quanon of various human rights such as the right to health and the right to life. It is hardly necessary to explain it, because environmental damage can damage and weaken all human rights that have been stated in the Universal Declaration and other human rights instruments (Anton and Shelton, 2008). In other words, engaging in activities that have a major impact on environmental damage that causes human life to be disturbed is a violation of human rights.

The goal of structuring every irrevocable human rights concept brings about social problems and their implication value since the international law is largely regarded as an inter-state law and that irreducible human rights are also applicable even when a country's life is in jeopardy. It is natural that the irreducible human rights should be identified as an intrinsic right to human rights (Koji, 2001).

The rights included in these non-derogable rights are provided for in Article 28I paragraph (1) of the 1945 Constitution. The rights that cannot be reduced under any circumstances include the right to life, the right not to be tortured, the right of freedom for thought and conscience, religious rights, the right not to be enslaved, the right to be recognized as a person before the law, and the right not to be prosecuted on the basis of retroactive law. The elucidation of Article 4 of Act No. 39/1999 on Human Rights, further explains what is meant by "under any circumstance" including war, armed conflict and / or emergency situations, whereas derogable rights are rights that are still reduced or limited by state compliance in certain circumstances. The same is also stipulated in Article 4 of Act No. 39 of 1999 on Human Rights and Act No. 12 of 2005 on the Ratification of the International Covenant on Civil and Political Rights.

According to the High Level Panel, the Secretary-General of the United Nations on threats, challenges and change, environmental degradation is one of the most serious threats to world stability and requires firm action to avoid potentially devastating conflicts (Galizzi, 2006).

Normatively, the realization of the right to a good and healthy environment is getting settled. It can be proved by the number of countries to include the right to the environment into the constitution of the state. However, the enforcement of environmental rights in the constitution of a country does not increase the possibility that other countries in the same region will accommodate the environmental rights in the constitution of their country. This, of coure, depends on the state of the country, is related to democratic culture, environmental conditions, demands of the people and others. But India is an example of a good country with respect to the right to the environment. The right to the environment as can be seen in Article 21 of the Indian Constitution is interpreted as a stronger fundamental right, which guarantees the right to life which includes the right to enjoy water and pollution free air to enjoy a full life. In fact, it can be run by the states.

\section{CONLUSION}

Based on the data and discussion it can be concluded that it is very urgent to initiate that the right to a good and healthy environment can be pushed into an irreducible right, especially when the countries condition are stable. This conclusion is also supported by the fact that a good and healthy environment is the foundation and construction for the fulfillment of other human rights, namely the right to health, economy, work, education, even the right to life. It is recommended by the United Nations to accommodate and develop the discourse to strengthen the idea of making the right to a good and healthy environment a non-derogable right.

\section{REFERENCES}

[1] Anton, Don and Dinah Shelton, 2008. Is the Environment a Human Rights Issue?, The Australian National University, College of Law.

[2] Ballard, Chris, 2001.Human Rights and the Mining Sector in Indonesia: A Baseline Study, Canberra: International Institute for Environment and Development.

[3] Brems, Eva, 2001. Human Rights: Universality and Diversity, London: Martinus Hijhoff Publishers.

[4] Brunne, Jutta, The Stockholm Declaration and The Structure and Processes of International Environmental Law.

[5] El Muhtaj, Majda, 2005. Hak Asasi Manusia dalam Konstitusi Indonesia, Jakarta: Prenada Media.

[6] ..........................., 2008. Dimensi-Dimensi HAM: Mengurai Hak Ekonomi, Sosial, dan Budaya, Jakarta: Rajawali.

[7] Galizzi, Paolo. 2006. FromStockholmt o NewYork,viaRioand Johannesburg:hast h e EnvironmentLost itsWayon theGlobal Agenda?Fordham International Law Journal, Vol.29, FordhamUniversitySchool ofLaw.

[8] Gellers, Joshua.

GreeningConstitutionswithEnvironmentalRights: Testingthe Isomorphism Thesis. University of California.

[9] Giandono, Roni dan Yulia Pasha, 2005. Hak Atas Lingkungan (Sebuah Kajian Prinsip-Prinsip HAM dalam Instrumen Nasional), Jakarta: Komnas HAM.

[10] Hancock, Jan.2003.Environmental Human Rights: power, ethics and law, London, Ashgate Publishing Company.

[11] Hunter, David al all, 2007. International Environmental Law and Policy, Foundation Press.

[12] Jack Donelly, 2003. Universal Human Rights in Theory and Practice, Ithaca: University Press.

[13] Keraf, Sonny, 2010. Etika Lingkungan, Jakarta: Kompas. 
[14] Machmud, Syahrul, 2007. Penegakan Hukum Lingkungan Indonesia, Bandung: Mandar Maju

[15] Makarao, Mohammad Taufik, Aspek-Aspek Hukum Lingkungan, Jakarta: PT Indeks.

[16] Martin, Francisco Forrest, 1997. International Human Rights Law \& Practice: Cases, Treties and Materials Documentary Supplement, Huge: Kluwer Law International.

[17] Mishra, Prajna Paramita \& Ayan Kumar Pujari, Impact of Mining on Agricultural Produktivity, Hyderabad, CESS.

[18] Muhammad, Chalid, dkk, 2005. Tambang dan Kemiskinan: Catatan Kecil Kasus Pertambangan di Indonesia 2001-2002, Jakarta: Jaringan Advokasi Tambang (JATAM).

[19] Rivkin, Dean Hill at all, 2010. Strip Mining and Grssroot Resistance in Applachia, Rsearch Paper, College of Law, The University of Tennesse.

[20] Sabon, Max Boli, 2009. Hak Asasi Manusia, Jakarta: Universitas Atma Jaya.
[21] Saleh, M. Ridha, 2005.ECOCIDE: Politik Kejahatan Lingkungan dan Pelanggaran Hak Asasi Manusia, Jakarta: Wahana Lingkungan Hidup Indonesia (WALHI).

[22] Salleh, Mohd Affandi, 2002. International Environmental Conventions and Treaties, International Law Book Services.

[23] Shelton, Dinah, 2002. Human Rights and Environment Issues in Multilateral Treaties, [The Background Papers reflect the views of the authors and not of UNEP or OHCHR], Geneva, University of Notre Dame.

[24] Shelton, Dinah, 2002. Human Rights and the Environment: Jurisprudence of Human Rights Bodies, Geneva: University of Notre Dame.

[25] Simons, Penelope and Lynda Collins, 2010. Participatory Rights in The Ontorio Mining Sector: An International Human Rights Perspective, Canada: Faculty of Law University of Ottawa.

[26] Tomuchat, Cristian, Human Rights Between Idealism and Realism, Oxford: Oxford University Press. 